\title{
Folat og medfødte misdannelser - Skal vi berike matvarer eller teste gener?
}

\author{
Camilla Stoltenberg \\ Statens institutt for folkehelse, Postboks 4404 Torshov, 0403 Oslo \\ tlf. 22042378 fax 22042351
}

Folat er et B-vitamin som finnes i lever, egg, grovt brød, frukt, grønne grønnsaker og mange andre matvarer. Vi vet nå at et tilstrekkelig inntak av folat er nødvendig blant annet for at hjernen skal utvikle seg og ryggmargen lukke seg normalt i fosterlivet. Hvor mye folat kvinner i fruktbar alder trenger er det imidlertid uenighet om og anbefalingene varierer fra land til land. Behovet varierer også fra kvinne til kvinne avhengig av hennes og barnets genetisk bestemte tilbøyelighet til å utvikle nevralrørsdefekter eller andre medfødte misdannelser.

\section{MAT, BERIKET MAT ELLER TABLETTER}

I 1914 hadde 99\% av løveungene i London Zoo ganespalte, men etter at dyrenes kosthold ble forbedret, ble det bare født 2 løveunger med denne misdannelsen, forteller Anne-Lise Bjørke Monsen i sin oversiktsartikkel om folat og medfødte misdannelser (1). Sannsynligvis var det folat som forebygget flere ganespalter hos løveungene. Lavt inntak av folat ved tidspunktet for befruktning eller tidlig i svangerskapet er muligens forbundet med leppe- og ganespalter, urinveis- og hjertemisdannelser, og misdannede lemmer. Sammenhengen mellom folat og nevralrørsdefekter er imidlertid best dokumentert $(1,2)$. En arbeidsgruppe nedsatt av Statens Ernæringsråd har nettopp levert sin rapport der behovet for økt folatinntak vurderes (2). Rapporten beskriver hvor lite vi vet om folatinntaket i Norge, men likevel er arbeidsgruppens konklusjon entydig når det gjelder folatinntaket hos kvinner i fruktbar alder: Det er for lavt til å forebygge medfødte misdannelser. Spørsmålet er hvordan folatinntaket skal økes. Skal vi berike matvarer med folat eller skal vi informere kvinner i fruktbar alder om folatrike matvarer og folattilskudd i form av tabletter? Statens Ernæringsråd vil forsøke å svare også på disse spørsmålene og har ned- satt en ny arbeidsgruppe som skal vurdere virkemidler og anbefalinger for økt folatinntak.

\section{GENER OG FOLKEHELSE}

Nevralrørsdefekter er sjeldne tilstander og oppdages ved fødselen hos omtrent 60 barn i Norge hvert år, det vil si hos 1 av 1000 fødte. De fleste kvinner som får barn med nevralrørsdefekter har ikke egentlig folatmangel, og de fleste kvinner får barn uten nevralrørsdefekter selv om folatinntaket er lavt. Mye tyder på at en mutasjon i genet som koder for enzymet metylentetrahydrofolat reduktase (MTHFR) fører til at folatstoffskiftet hos fosteret blir svekket. Ved hjelp av folat-tilskudd kan dette antagelig kompenseres, og den genetiske feilen kommer ikke til uttrykk. Sannsynligvis er det en rekke gener knyttet til utviklingen av misdannelser ved folatmangel. Genene kan finnes hos moren eller hos barnet, og hyppigheten av genene varierer antagelig mellom befolkninger. Kanskje kan det tenkes at anbefalingene for folatinntak i fremtiden også vil variere avhengig av hvilken utbredelse de ulike genene har. Hvis den genetiske disposisjonen finnes hos moren vil man kunne tenke seg en situasjon der det vil være mulig å teste en kvinne for denne disposisjonen og gi folat-tilskudd på individuelt grunnlag. Selv om disse problemstillingene ikke er aktuelle i øyeblikket, vil de snart kunne gi nye arbeidsoppgaver for de som skal vurdere tiltak og foreslå anbefalinger. Skal vi alle tvinges til å spise folat-beriket mel hvis vi lett kan finne fram til de som virkelig trenger mer folat enn andre?

Samspillet mellom gener og miljø avdekkes gradvis for folat og medfødte misdannelser og viser oss noen av de problemstillingene vi har foran oss når det gjelder å anvende molekylærgenetiske oppdagelser i forebyggende arbeid og helsepolitikk (3).

\section{REFERANSER}

1. Monsen, A-LB. Folsyre og medfødte misdannelser. Norsk Epidemiologi 1997; 7 (1): 19-22.

2. Statens Ernæringsråd. Vurdering av behovet for økt folatinntak. Rapport fra en arbeidsgruppe nedsatt av Statens ernæringsråd. Oslo, mars 1997.

3. Khoury MJ. From genes to public health: the applications of genetic technology in disease prevention. $A m J$ Public Health 1996: 86 (12): 1717-1722. 